\title{
Grossly Negative and Microscopically Negative Surgical Margin
}

National Cancer Institute

\section{Source}

National Cancer Institute. Grossly Negative and Microscopically Negative Surgical

Margin. NCl Thesaurus. Code C120288.

The absence of tumor cells at the edge of a surgically excised specimen, both

macroscopically and microscopically. 